In ancient days, when the climate of the Turkish empire was favorable, the ancestors of some of the present inhabitants were the leaders of civilization. To-day their descendants are crushed and discouraged by the insurmountable obstacles of nature. No wonder their spirit is broken, their children ignorant, their religion corrupt, and their government diabolical.

Truly Turkey is the sick nation of Europe, and her civilization corresponds to her physical environment.

This does not mean that she is forever doomed to misgovernment, race hatred and massacre. It does mean, however, that there is little hope of any favorable development from within.

We now attain to the climax of the book in a consideration of Germany and her Neighbors, and the Great War. Racial character, Huntington says, "is the effect of physical environment acting upon generation after generation." The Germans are living in one of the most invigorating climates, one that is superior to that of her enemies who live east and south of them, and it has made them the virile and persisting people that they are.

No other nation in the world has so many people who live under a highly stimulating climate. The German devotion to the national cause is like that which made early Rome so formidable.

Wherever and whenever the climate is stimulating, civilization seems to rise to a high level. The character of the civilization of course varies according to the race and training of the people. Yet no matter what the race, it seems under such circumstances to acquire the power to originate new ideas, to stick to them until they are carried out, and to impress its rule and its civilization upon the less favored people with whom it comes in contact.

\section{Charles Sohuohert}

\section{NEW ACTIVITIES IN THE HISTORY OF SCIENCE}

THE active interest in the history of science which exists at the present time in Europe is indicated by the numerous publications which are appearing and announced in this field.

In Italy the journal Scientia (Rivista di Scienza), International Review of Scientific Synthesis, is in its thirteenth year of publica- tion. The present editor is $\mathrm{E}$. Rignano, whose works are favorably known to American readers. This is a monthly publication (subscription at 33 francs per year, Felix Alcan, publishers, Paris), with articles in French, Italian and English, but articles in Italian and English are repeated in French translation. The title indicates the purpose, synthesis of science, of the journal, particularly to counterbalance the ill effects of over-specialization and also to have due regard for the bonds of unity among the different sciences. The social sciences and the history of science are included within the program of this publication. It deserves the hearty support of all scientists, particularly the support by subscription of college and technical libraries and by individuals.

Professor Gino Loria has published for nearly twenty years the quarterly journal, Bollettino di Bibliografia e Storia delle Scienze Matematiche (Torino, Rosenberg et Sellier, Via Maria Vittoria, 18). The editor is notable among historians of mathematics as a mathematician of the first rank, contributing equally to the field of pure mathematics and to the history of the science. This journal is always interesting and instructive, particularly valuable to all students of mathematics.

In March of this year appeared the first number of a new Italian publication, quarterly, devoted entirely to the history of science, the Archivio di Storia della Scienza. The editor, Professor Aldo Mieli, of the University of Rome, is a well-known contributor to the fields of the history and philosophy of the sciences. Each volume of the Archivio will consist of about 500 pages (foreign subscription 35 francs, Dott Attilio Nardecchia, Via dell'Umilta, 14, Rome 19). While particular attention is to be paid to Italian science and scientists, all publications in the history of the various sciences and relating to the philosophy and development of science come within the range of the journal.

The first number contains the following articles and departments: G. B. De Toni, "Francesco Griselini, viaggiatore e natural- 
ista veneziano del sec. XVIII."; Ant. Favaro, "Matteo Carosio (Amici e corrispondenti di Galileo. XLI.)"; Gino Loria, "Per una storia della matematica nel secolo XIX."; Andrea Corsini, "L" influenza" oggi e nel passato"; Studi e Note Vinciane Proemio, D. T. Per l'edizione nazionale delle opere di Leonardo, Notizie varie; Bibliografia metodica dei lavori di storia della scienza publicati in Italia; Analisi critiche: R. Almagià, Cristoforo Colombo (G. Stefanini); U. Viviana, Andrea Cesalpino; R. Marcolongo, Il problema dei tre corpi; W. Libby, An Introduction to the History of Science (A. Mieli); Gli Scienziati Italiani, Aggiunte, note e discussiono; Notizie e Commenti: Organizzazioni italiane per promuovere lo studio della storia della scienza (A. Mieli). La storia della scienza nelle Università-Notizie varie.

Due credit must be given, even to-day, to the Germans for their activity in the publication of journals of an international character. However, Americans should now realize the desirability of stimulating and encouraging Italian, English and other European scientific publications of an international character. The revived Belgian journal Isis, now published by Dr. George Sarton and Dr. Charles Singer, of Oxford, should be remembered in this connection.

The best way to stimulate these publications is by personal subscription and by personal interest on the part of scientists in urging upon librarians the subscription to these enterprises.

\section{UNIVERSITY OF MIOHIGAN}

\section{LoUIS C. KaRPINSKI}

\section{SPECIAL ARTICLES}

THE MOTION OF A GRAVITATING NEEDLE ${ }^{1}$

1. Static Elongations.-The apparatus ${ }^{2}$ with which I am working is of the simplest character, but judiciously designed. Two shots ( $m=.6$ gram), one at each end of a straw shaft $22 \mathrm{~cm}$. long (diagram 1a), are supported by a long quartz fiber, fixed with

1 Advance note from a Report to the Carnegie Institution of Washington, $D$. C.

2 Proc. Nat. Ac. Sc., IV., 338, 1918. cement above and below. The attracting weight ( $M=1$ kilog., or more) can easily be moved from one side to the other and definitely placed by a smooth-working crank mechanism, between stops. Observations are made in a dark room (except for distant lamp light), in a damp, semi-subterranean basement, in midsummer, with very fair constancy of temperature and no electric charges. The motion of the needle is essentially creeping with a period (if I may so call it) of 20 or 30 minutes. The scale distance is over 4 meters from the little mirror at the center of the shaft. The abserver keeps out of the way.

Under these circumstances reasonably constant scale deflections, for periods of alternation exceeding 30 minutes would be expected; but the reverse of the case. Here is an example of the successive mean excursions or double amplitudes of the needle during the day:

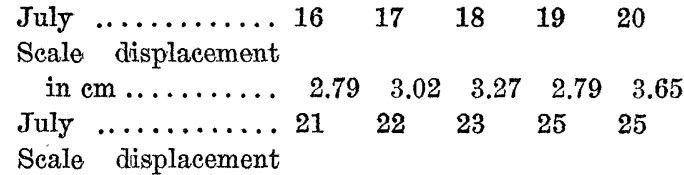

The values of the morning and afternoon readings were equally different. Individual excursions may run as high as $6 \mathrm{~cm}$. on certain days, though the behavior is throughout, of course, quite systematic.

2. Triplets for three-minute Periods.-The results for short period alternations of the pull of $M$ (3 minutes in the examples given, Figs. $1,2,3)$ are equally bizarre; though, here they become interesting. In Fig. 1, the turning points of $M$ are indicated by little circles, $R$ and $L$ are pulls to right and to left, respectively, and the mean double amplitude of the successive triplets are marked on the curves. There is drift throughout the figure; otherwise the behavior is about what would be expected. Inertia apparently carries the ball a little time after the gravitational pull has changed sign. But for this, there would be a phase difference of $90^{\circ}$ as there should be. Moreover, the motion of the needle, after turning, is uniform. 